\title{
Effect of wave exposure on growth and mortality rates of the mussel Perna perna: bottom-up regulation of intertidal populations
}

\author{
C. D. McQuaid*, T. L. Lindsay \\ Department of Zoology and Entomology, Rhodes University, Grahamstown, South Africa
}

\begin{abstract}
The effect of wave exposure on the growth of low-shore populations of Perna perna (Linnaeus) was determined using 3 independent approaches at 6 sites on the south coast of South Africa: (1) Individual marking; notches were filed on the growing edges of mussels in situ. After $111 \mathrm{~d}$, growth from the mark to the new growing edge was measured. (2) Internal shell-growth bands; mussels from the mark-recapture experiment were used to establish that growth bands are laid down tidally. Unmarked individuals were then used to measure growth over the last 60 tides. (3) Shepherd's length-composition analysis (SLCA); growth rates were determined from length-frequency distributions in 11 samples collected at 6 wk intervals over 15 mo. All 3 approaches showed that growth rate was approximately twice as fast on exposed as on sheltered shores (ANCOVA, p < 0.05 in all cases). Mean length for the first year of growth (averaged for the 3 methods) was 47 and $22 \mathrm{~mm}$, respectively. There were, however, considerable differences among methods. Marking provided the lowest estimates of growth rates, and SLCA the highest. The mean mortality index $\left(Z \mathrm{yr}^{-1}\right)$ was significantly higher and annual survival rate lower for exposed shores, indicating faster turnover under exposed conditions. Mean longevity on exposed shores (2.6 yr) was only one-third of estimated longevity on sheltered shores $(6.7 \mathrm{yr})$. These findings show that degree of exposure has important interactions with growth and mortality of mussels on the low shore, and that these effects are independent of the effects of exposure on density. The findings also indicate strong bottom-up regulation of mussel populations.
\end{abstract}

KEY WORDS: Growth $\cdot$ Mortality $\cdot$ Mussels $\cdot$ Perna perna $\cdot$ Wave exposure $\cdot$ Bottom-up regulation Resale or republication not permitted without written consent of the publisher-

\section{INTRODUCTION}

Mussels are an important ecological component of rocky shore communities around the world (Dayton 1971, Menge 1976, Frechette \& Bourget 1985, Suchanek 1985, Griffiths \& Hockey 1987, Grant et al. 1993, Dye et al. 1994), and often show differences in population structure with different degrees of wave action. This may be a species- or site-specific effect. In some areas, mussels are smaller on shores with strong

*E-mail: c.mcquaid@ru.ac.za wave action (Seed 1969, Jørgensen 1976, Alvarado \& Castilla 1996), while in South Africa the opposite is true. Low-shore populations of Perna perna on the south coast of South Africa differ markedly between exposed and sheltered shores. Both mean and maximum sizes of mussels are greater on exposed shores (McQuaid et al. in press). This could be due to different growth rates and/or different mortality rates and implies that population dynamics differ between these 2 shore types. Given the importance of mussels as a staple in a subsistence-level fishery in parts of South Africa (Dye 1988, Lasiak \& Dye 1989, Lasiak 1991), this could have important implications for management of an exploited natural resource. 
The growth rate of a population in a fishery can be estimated by several methods, and at the outset there is often uncertainty about which approach is best. The primary advantage of using more than 1 technique is corroboration of results from independent measurements. In this study we used 3 independent approaches to measure growth rates of Perna perna under different exposure regimes on shores in close proximity to one another. Mortality may be as important as growth in the dynamics of mussel production (Dickie et al. 1984), and our growth findings were coupled with estimates of mortality to clarify the interactions of degree of exposure with growth and turnover.

\section{MATERIALS AND METHODS}

Studies were undertaken on the south coast of South Africa in the vicinity of Port Alfred $\left(33^{\circ} \mathrm{S}, 27^{\circ} \mathrm{E}\right)$. The sites are approximately 3 to $30 \mathrm{~km}$ apart and span $70 \mathrm{~km}$ of coastline. This coast has equal semi-diurnal tides, with a maximum tidal range of $\sim 2 \mathrm{~m}$. Most shores are relatively exposed to wave action, but the degree of exposure varies. Six localities were classified both qualitatively and quantitatively, using dynamometers (Palumbi 1984), as either exposed (Diaz Cross, Kwaai Hoek, Fish River) or sheltered (Rufanes, Mgwalana, Riet River; authors' unpubl. data). Exposed and sheltered sites were interspersed along the coast. Growth rates of Perna perna (Linnaeus) were measured at each site along a $20 \mathrm{~m}$ stretch of low-shore mussel bed with $100 \%$ cover. During analysis, normality of data was examined using the Kolmogorov-Smirnov test and homogeneity of variance using the Bartlett test. Growth rates were measured using 3 independent techniques based on fundamentally different approaches: individual marking, growth-band analysis and length-frequency distributions.

Individual marking. Mussels were marked in situ at each site ( $\mathrm{n}=245$ to 330 ) by filing a small notch ( $1 \mathrm{~mm}$ ) in the growing edge of the shell (Ekaratne \& Crisp 1982). After $111 \mathrm{~d}$, the mussels were removed and the initial shell lengths (apex to notch) and the final lengths (apex to growing edge) were measured to the nearest $0.1 \mathrm{~mm}$ with vernier callipers. Mussels $<25 \mathrm{~mm}$ were difficult to handle and were excluded. The sex of each mussel was determined by examination of the gonad colour (Lasiak 1986). Growth rates were calculated separately for males and females at each site.

Growth-band analysis. The frequency with which internal growth bands were laid down in the shell was determined for mussels from the marking experiment, which had been in the field for a known period of $111 \mathrm{~d}$. Ten individuals (34 to $82 \mathrm{~mm}$ ) were used from each of the Kwaai Hoek (exposed) and Mgwalana (sheltered) localities. Growth bands were identified using acetate peels, following Pentilla et al. (1988) and Richardson (1989). Growth was measured to the nearest $0.01 \mathrm{~mm}$. The mean number of bands per day was $1.87( \pm$ SD 0.19$)$ at Mgwalana and $1.89( \pm 0.23)$ at Kwaai Hoek, indicating a tidal pattern, i.e. 2 low tides $\mathrm{d}^{-1}$. There was no significant difference in the number of bands laid down at the 2 sites (1-way ANOVA; $F=$ 0.04, df $=18, \mathrm{p}=0.85$ ).

The distance between successive tidally induced bands has been shown to represent the actual linear increase in shell length (Richardson et al. 1990). Once it was established that internal growth bands were laid down tidally $\left(2 \mathrm{~d}^{-1}\right)$, growth over the last 60 bands was measured for unmarked mussels. Three mussels in each of 3 size classes (20 to 25,40 to 45 and 70 to $75 \mathrm{~mm}$ ) were used for each site. The initial length and growth over the last 60 tides were measured for each mussel. Failure in the acetate stage, resulting in indistinct slides, made it necessary to pool the results for each exposure category. Thus, the effects of exposure could be ascertained but not of site. The effects of exposure on growth rate were analysed using ANCOVA (with initial length as a covariate) on data from individual marking and on growth-band data. Growth rates from the marking method were also examined at the finer scale of site. Normality and homogeneity were achieved $(p>0.05)$ after $\log _{10}(n+1)$-transformation.

For the marking and growth-band methods the Gulland-Holt plot (Gayanilo et al. 1996) was used to generate the parameters $K$ (growth coefficient) and $L_{\infty}$ (theoretical maximum length), required for the von Bertalanffy growth equation, which converts length data to estimated age (see Sparre \& Venema 1993). These parameters were also used to generate values for phi prime $\left(\Phi^{1}\right)$, which gives an index of overall growth performance (Pauly \& Munro 1984, Tomalin 1995).

Length-frequency distribution. Length frequencies at each site were obtained at approximately 6 weekly intervals (11 occasions) over a period of 15 mo (July 1995 to October 1996). Samples of $>200$ mussels per site were collected using 4 or $510 \times 10 \mathrm{~cm}$ quadrats placed randomly in areas of approximately $100 \%$ mussel cover. All mussels $>1 \mathrm{~mm}$ were measured in the laboratory, using an image-analysing program (see McQuaid et al. in press). Regression of lengths obtained for the same individuals (size range 2 to $80 \mathrm{~mm}$; $\mathrm{n}=63$ ) using vernier callipers and image-analysis gave a regression coefficient of 0.9996 .

Shepherd's length-composition analysis (SLCA; Shepherd 1987) was carried out on $3 \mathrm{~mm}$ size classes using the software package FiSAT (Gayanilo et al. 1996). $L_{\infty}$ was estimated using the Powell-Wetherall plot (Wetherall 1986) on pooled length-frequency data 
Table 1. Perna perna. Two-way ANCOVA on effect of sex and site on growth rate. Growth and initial length were log ${ }_{10}^{-}$ transformed

\begin{tabular}{|c|c|c|c|c|c|}
\hline Source of variation & $\mathrm{df}$ & SS & MS & $F$ & $\mathrm{p}$ \\
\hline Initial length (co-variate) & 1 & 23.90 & 24.90 & 632.30 & $<0.0001$ \\
\hline Site (factor) & 5 & 40.77 & 8.15 & 207.01 & $<0.0001$ \\
\hline Sex (factor) & 1 & 0.01 & 0.01 & 0.34 & 0.5656 \\
\hline Interaction of factors & 5 & 0.64 & 0.13 & 3.25 & 0.0065 \\
\hline Residual & 710 & 27.96 & 0.04 & & \\
\hline
\end{tabular}

for each site. The optimal combination of $L_{\infty}$ and $K$ for each site was inserted into a von Bertalanffy equation.

Mortality. Size-distribution data were used to generate catch curves for each site, using FiSAT (see Pauly 1990). Total mortality $(Z)$ was estimated from the gradient of the catch curve after excluding the first size class, as it appeared to be undersampled (see Pauly 1990, Pauly et al. 1995). Percentage survival rate per annum and longevity were calculated for each site as: survival rate $(\%)=\mathrm{e}^{-Z} \times 100$ and longevity $=-\ln (0.01) / M \%$ where $M=$ natural mortality. This assumes no fishing mortality, which is true for the study areas.

\section{RESULTS}

The results from all 3 methods showed faster growth rates for Perna perna at exposed shores than sheltered shores and in younger mussels than older ones.

\section{Individual marking}

Growth rates did not differ significantly between males and females (2-way ANCOVA, $p>0.05$, Table 1). However, for 1 site, Mgwalana, there was a small, significant difference (1-way ANOVA, $p=0.045$; male growth $>$ female growth). This resulted in a significant interaction between factors (Table 1). As sex did not generally have a significant effect on the growth rates for the remaining sites, all further analyses were undertaken on combined male and female data. Growth decreased with initial size and was faster at the exposed sites (Fig. 1). One-way ANCOVA

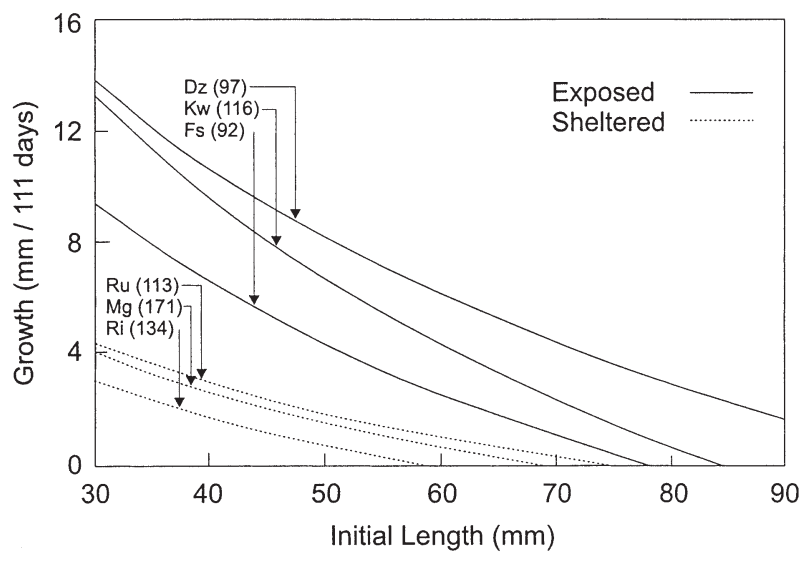

Fig. 1. Perna perna. Growth of marked mussels using untransformed data. Exposed sites are Dz (Diaz Cross), Kw (Kwaai Hoek), and Fs (Fish River); sheltered sites are Ru (Rufanes), Mg (Mgwalana), and Ri (Riet River). Sample size is given in parentheses for each site

showed that both site and the co-variate (initial length) had significant effects on growth ( $p<0.05$, Table 2$)$. There were significant differences among all sites (Tukey's multiple-range test, $\mathrm{p}<0.05$ ), with sheltered sites ranking below exposed sites. Likewise, 1-way ANCOVA on data pooled for sites showed a significant effect for exposure (Table 3A).

The growth parameters $\Phi^{1}$ and $K$ were significantly higher on the exposed shores (Student's $t$-tests, $\mathrm{p}<0.05$ in both cases). Although $L_{\infty}$ was lower at sheltered sites (Table 4), the difference was not significant ( $p>0.05$ ). The higher $\Phi^{1}$ and $K$ values indicate that, on exposed shores, mussels show higher growth performance and reach their maximum theoretical lengths $\left(L_{\infty}\right)$ faster.

Table 2. Perna perna. One-way ANCOVA on relationship between site, initial length and growth rate. Data from mark-recapture method were $\log _{10}$-transformed

\begin{tabular}{|lrrrrr}
\hline Source of variation & df & SS & MS & $F$ & p \\
\hline Site (factor) & 5 & 41.45 & 8.29 & 207.13 & $<0.0001$ \\
Initial length (co-variate) & 1 & 25.06 & 25.06 & 626.16 & $<0.0001$ \\
Residual & 716 & 28.66 & 0.04 &
\end{tabular}


Table 3. Perna perna. One-way ANCOVA on relationship between exposure, initial length and growth rates for (A) Data from individual marking method (data were $\log _{10}$-transformed) and (B) data from growth bands

\begin{tabular}{|c|c|c|c|c|c|}
\hline Source of variation & $\mathrm{df}$ & SS & MS & $F$ & $\mathrm{p}$ \\
\hline \multicolumn{6}{|l|}{$\mathbf{A}$} \\
\hline Exposure (factor) & 1 & 35.74 & 35.74 & 748.66 & $<0.0001$ \\
\hline Initial length (co-variate) & 1 & 20.63 & 20.63 & 432.15 & $<0.0001$ \\
\hline Residual & 720 & 34.37 & 0.05 & & \\
\hline \multicolumn{6}{|l|}{ B } \\
\hline Exposure (factor) & 1 & 23.74 & 23.74 & 107.92 & $<0.0001$ \\
\hline Initial length (co-variate) & 1 & 9.61 & 9.61 & 43.67 & $<0.0001$ \\
\hline Residual & 31 & 6.82 & 0.22 & & \\
\hline
\end{tabular}

Von Bertalanffy growth curves showed that, at 1 and 2 yr of age, mussels were twice as long at exposed as at sheltered sites (Fig. 2). Conversely, individuals of similar lengths were substantially older at sheltered sites.

\section{Growth-band analysis}

Sample sizes per shore were low, and results were pooled as exposed or sheltered. Both initial length and exposure had significant effects on mussel growth rate (Table 3B; 1-way ANCOVA, p < 0.05). Growth was faster for smaller mussels and under exposed conditions (Fig. 3). $\Phi^{1}, L_{\infty}$ and $K$ were all higher at exposed sites (Table 4 ).

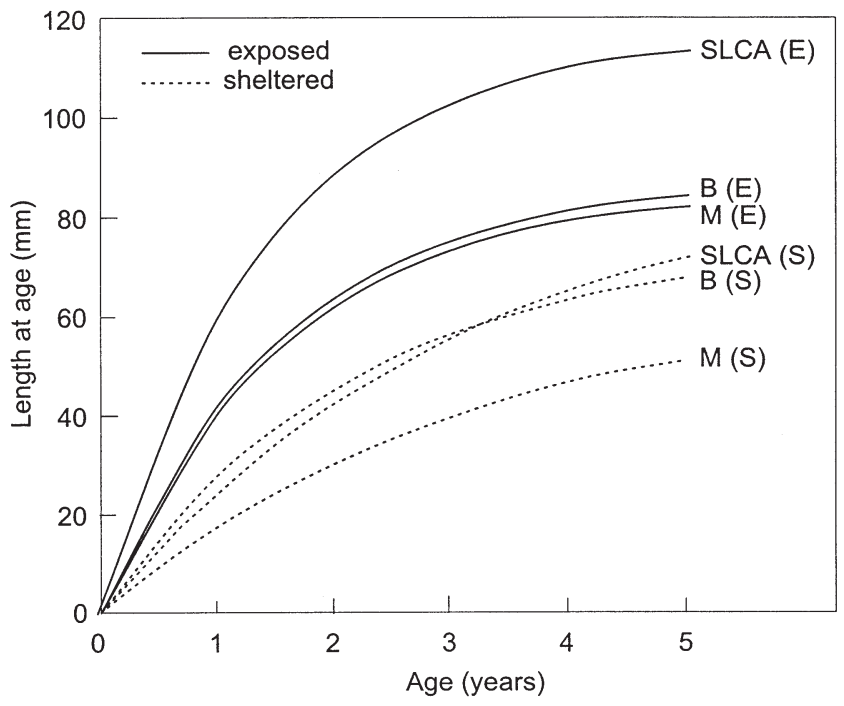

Fig. 2. Perna perna. Von Bertalanffy growth curves generated from growth rates obtained by individual marking method (M), growth band (B) and cohort analysis (SLCA) (sites pooled). $\mathrm{E}=$ exposed shores; $\mathrm{S}=$ sheltered shores. Mean lengths in $\mathrm{mm}$ (pooled for all methods) for $1 \mathrm{yr}$ of age are exposed $=47.06$ $( \pm$ SD 10.50), sheltered $23.07( \pm 5.13)$; and for $2 \mathrm{yr}$ of age are exposed $=71.24( \pm 14.96)$, sheltered $=39.14( \pm 7.88)$

\section{Length-frequency distributions}

Although cohorts were not easy to identify, there was 1 cohort at all sites which could be traced from recruitment in November 1995/January 1996 through to August/September 1996. Mean length at $1 \mathrm{yr}$ was greater at exposed sites (Fig. 2). Younger mussels grew faster than older ones on both shore types. $\Phi^{1}, L_{\infty}$ and $K$ were all significantly higher for the exposed shores than for the sheltered shores (Table $4 ; t$-tests, $\mathrm{p}<0.05$ in all cases).

$\Phi^{1}$ values were positively correlated with wave force at individual sites (methods pooled) ( $\mathrm{r}=0.71, \mathrm{p}<0.05$, $\mathrm{n}=6) . \Phi^{1}$, calculated from marking and SLCA, was negatively correlated with adult density $(\mathrm{r}=-0.68, \mathrm{p}<$ $0.05, \mathrm{n}=12$, Fig. 4). Although there was a general trend of decreasing $\Phi^{1}$ with increasing density $\left(\mathrm{r}^{2}=\right.$ 0.68), the degree of exposure was important. Packing densities at Mgwalana (sheltered) and Fish River (exposed) were almost identical, but $\Phi^{1}$ values were very different (Fig. 4).

Table 4. Perna perna. Comparison of $L_{\infty}, K$, and $\Phi$ values generated at exposed and sheltered shores using mark-recapture (MR), growth band (GB), and Shepherd's length-composition analysis (SLCA). Means are presented for mark-recapture and Shepherd's method, as replication of sites was undertaken

\begin{tabular}{|lrcc|}
\hline Method & \multicolumn{1}{c}{$L_{\infty}$} & $K$ & $\Phi$ \\
\hline Exposed & & & \\
MR & 85.85 & 0.64 & 3.69 \\
GB & 88.05 & 0.64 & 3.70 \\
SLCA & 117.44 & 0.70 & 3.98 \\
Sheltered & & & \\
MR & 65.61 & 0.31 & 3.14 \\
GB & 76.98 & 0.44 & 3.42 \\
SLCA & 91.94 & 0.31 & 3.40 \\
& & & \\
\hline
\end{tabular}




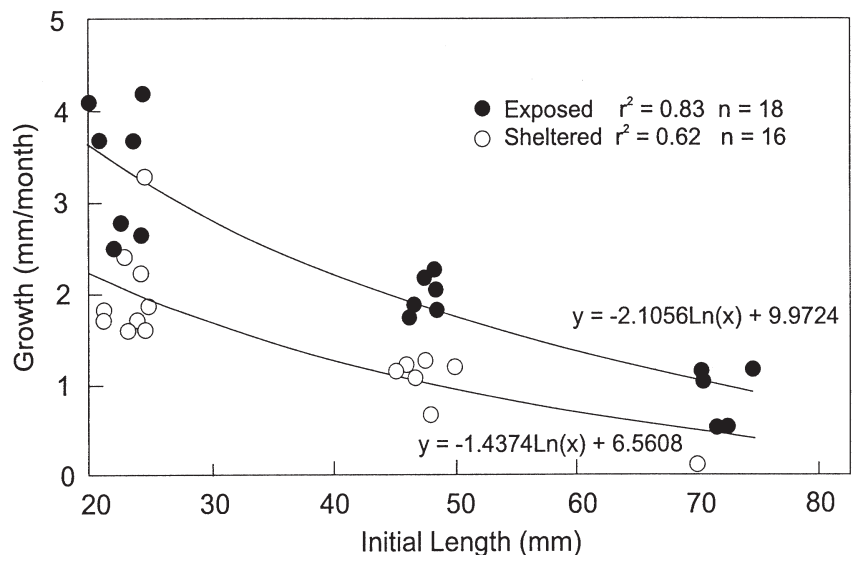

Fig. 3. Perna perna. Pooled growth rates for exposed and sheltered sites obtained from growth-band data for a $30 \mathrm{~d}$ period (60 tides)

\section{Mortality}

Total mortality rates $\left(Z^{-1}\right)$ were significantly higher at the exposed shores (Table $5 ; t=4.8338, \mathrm{p}=0.0084$ ). As a result, calculated longevity was significantly higher (in fact 2.6 times greater) for sheltered shores $(t=3.295, \mathrm{p}=0.0301$, Table 5). There was a significant linear relationship between the estimates of growth performance $\left(\Phi^{1}\right)$ and corresponding estimates of mortality $\left(Z ; \mathrm{p}<0.05, \mathrm{r}^{2}=0.9239\right)$.

\section{DISCUSSION}

Intertidal animals can show great plasticity in growth (Seed 1968, 1976, Cerrato \& Keith 1992, van Erkom Schurink \& Griffiths 1993), and earlier studies, including transplantation experiments, have shown that local conditions strongly influence growth rates of mussels (e.g. Seed 1969, Kautsky et al. 1990, Arnold et al. 1991). Although it is difficult to isolate the effect of 1

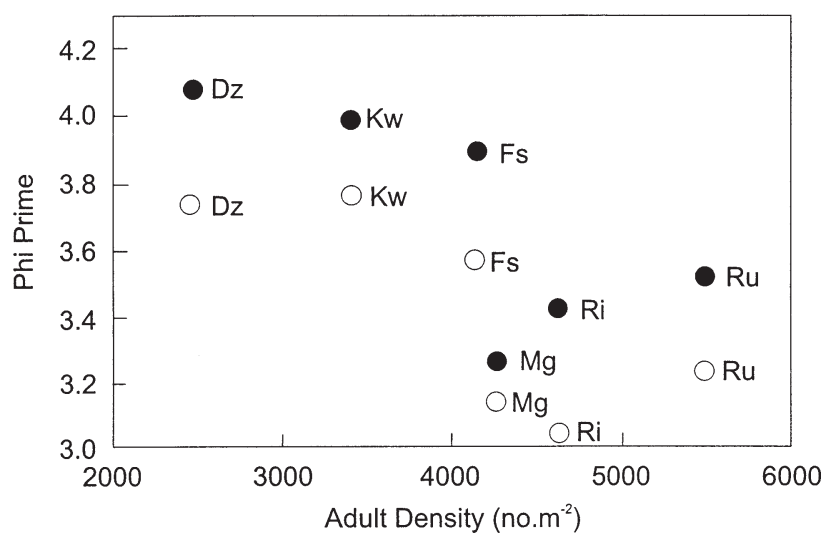

Fig. 4. Perna perna. Relationship between mean density of mussels and $\Phi^{1}$ (index of overall growth performance) obtained for each site using marking method (O) and cohort analysis (SLCA) (๑). Site abbreviations as in Fig. 1

particular factor in natural populations, several authors have documented the importance of wave action to growth rates (Jones \& Demetropoulos 1968, Raubenheimer \& Cook 1990). The effect of wave action may be species specific, as an increase in wave exposure may lead to either increased (van Erkom Schurink \& Griffiths 1993), or decreased (Seed 1968, Jørgensen 1976) growth rate. We found that significant differences in growth rates in populations of Perna perna separated at scales of $10 \mathrm{~s}$ of kilometers were unequivocally linked to variations in wave action.

The 3 methods used all showed higher growth rates for smaller mussels, as expected, but they also all showed that mussels grew twice as fast on exposed as on sheltered shores. There were differences in the absolute values obtained, but the 3 methods were ranked in the same order under both exposure regimes (Fig. 2). Length-frequency analysis was laborious and produced the highest estimates of growth rate, while mark-recapture produced the lowest, presumably because filing the growing margin caused a growth

Table 5. Perna perna. Total annual mortality $(Z)$ calculated from total length-frequency data obtained over 15 mo. Correlation coefficient for each curve for each site is included

\begin{tabular}{|c|c|c|c|c|c|}
\hline Site & $Z^{-1}$ & $\mathrm{r}^{2}$ & Survival (\%) & Longevity (yr) & Mean $\pm \mathrm{SD}$ \\
\hline \multicolumn{6}{|l|}{ Exposed } \\
\hline Diaz Cross & 1.82 & 0.83 & 16.20 & 2.53 & \\
\hline Kwaai Hoek & 2.12 & 0.87 & 12.00 & 2.17 & $2.59 \pm 0.47$ \\
\hline Fish River & 1.48 & 0.96 & 22.76 & 3.11 & \\
\hline \multicolumn{6}{|l|}{ Sheltered } \\
\hline Rufanes & 0.94 & 0.98 & 39.06 & 4.90 & \\
\hline Mgwalana & 0.51 & 0.92 & 60.05 & 9.03 & $6.72 \pm 2.11$ \\
\hline Riet River & 0.74 & 0.93 & 47.71 & 6.22 & \\
\hline
\end{tabular}


check. The use of chemicals such as tetracycline and calcein as internal shell markers offers a better alternative (Dey \& Bolton 1978, Kaehler \& McQuaid 1999a). Estimates of maximum theoretical length $\left(L_{\infty}\right)$ obtained by the 3 techniques showed the same ranking as growth estimates: SLCA > growth bands > marking. In fact the largest mussels measured were longer (by up to $10 \mathrm{~mm}$ ) than the highest estimate of $L_{\infty}$ for 3 of the 6 shores.

As well as significant effects of wave action on growth rates, we found a positive correlation between the maximum wave force measured by dynamometers and overall growth performance $\left(\Phi^{1}\right)$. Food supply is perhaps the single most important factor in determining mussel growth rates (Seed 1969, Griffiths 1980a,b, Tsuchiya 1980, Newell \& Shumway 1993). Greater water flow over the gills increases growth in mussels (van Erkom Schurink \& Griffiths 1993), while wave action and tidal currents maintain food in suspension and could make more food available (Griffiths 1980a,b, Bayne 1993). When food is limited, intraspecific competition becomes important and the number of individuals competing for it can affect growth rates (Kautsky 1982, Bertness \& Grosholz 1985). We found a negative relationship between growth performance $\left(\Phi^{1}\right)$ and the density of adults $(>15 \mathrm{~mm})$, which is in accordance with this suggestion. However, our results indicate that this relationship is simply a correlation and that the real effect on $\Phi^{1}$ is caused by wave action. Although densities at $100 \%$ cover were similar at Mgwalana and Fish River (which is much more wave-exposed), $\Phi^{1}$ values were quite different (Fig. 4). This implies that, although mean packing densities were significantly greater on sheltered shores, the lower growth recorded for these shores was actually a response to wave action and independent of density. Growth performance and density are likely to respond independently to wave action through the latter's effects on food availability and recruitment/wave-induced mortality respectively (Jones \& Demetropoulos 1968, Berry 1978, Griffiths 1980a, Eyster \& Pechenik 1987, van Erkom Schurink \& Griffiths 1993, McQuaid \& Lindsay unpubl. data).

Like growth rates, maximum lengths recorded over 15 mo were also greater for exposed shores, as found in a single, detailed survey of 18 sites along this coast (McQuaid et al. in press). Jones \& Demetropoulos (1968) found that the average length of blue mussels Mytilus edulis, increased as exposure increased, but others have found the opposite (Seed 1969, Jørgensen 1976, Alvarado \& Castilla 1996). The predominance of smaller individuals on more exposed shores could reflect greater predation on sheltered shores (Menge 1976), or dislodgment of large mussels by waves on exposed shores (Harger \& Landenberger 1971, Griffiths 1981, Paine \& Levin 1981, Denny 1987). Our results indicate that mussels are larger on exposed shores because their much faster growth offsets the higher mortality rates and lower longevity which we measured.

Mortality may be as important as growth in the overall dynamics of mussel production (Dickie et al. 1984) and can vary enormously depending on environmental conditions. Mortality for Mytilus edulis ranges from 95 to $100 \% \mathrm{yr}^{-1}$ in Morecambe Bay (Dare 1976) and 6 to $7 \% \mathrm{yr}^{-1}$ in Scottish lochs (Stirling \& Okumus 1994). Our entire study area stretched for approximately $70 \mathrm{~km}$ and we found that mortality differed dramatically on shores separated by $10 \mathrm{~s}$ of kilometers. Longevity showed an inverse relationship with growth (see also Seed 1969, Bayne 1976, Dare 1976, Berry 1978) and was lowest on exposed shores, where growth was faster. The mean annual mortality rate was $83 \%$ for exposed shores, but only $51 \%$ for sheltered shores. These are comparable to the $74 \%$ calculated for Perna picta in Morocco (Shafee 1992). One cause of mortality which is known to be greater on exposed shores is shell degradation caused by endolithic cyanobacteria (Kaehler 1999, Kaehler \& McQuaid 1999b).

In terms of occupying space, growth may offset mortality in mussels. Small Mytilus edulis can double their length in a year, and this is sufficient to compensate for $60 \%$ mortality $\mathrm{yr}^{-1}$ without an increase in free space (Petraitis 1995). We found that the higher growth rates of Perna perna on exposed shores compensate for the higher mortality rates they experience. This allows them to maintain cover at levels similar to populations on sheltered shores, despite differences in size and density.

This is a second South African example of bottom-up regulation (Menge 1992) of intertidal communities. Bustamente et al. (1995) showed that densities of limpet populations on the west coast depended on the rate of kelp input. In this study we found that growth rates of mussels are affected by wave action (presumably as this dictates rates of food supply), and it has previously been shown that predator biomass in South Africa is correlated with filter-feeder biomass (McQuaid \& Branch 1985, see also Menge 1992). Both filter-feeder and total animal biomass are significantly higher on exposed than sheltered shores (McQuaid \& Branch 1985), and this may indicate the importance of energy subsidies into the system through the medium of wave action. Higher growth rates on exposed shores also provide a mechanism which can explain the shift in dominance between filter-feeders on exposed shores and algae on sheltered shores recorded for the South African coast (McQuaid \& Branch 1985).

The degree of wave action is a continuous variable, but subjective classification of shores as exposed or 
sheltered can be linked to real differences in populations. Both growth and mortality rates were much higher for mussels on more exposed shores, resulting in different size structures and suggesting much more rapid turnover rates in exposed populations. The implication is that wave action does not act only as a form of stress on the shore; indeed wave action favours some species (McQuaid \& Branch 1984). More importantly, the effects of water movement on food supply for filter-feeders are analogous to the effects of nutrient supply to macroalgae, allowing bottom-up regulation of populations (cf. Menge 1992). A further implication is that shores with different degrees of wave action may also differ in their carrying capacity and the ability of mussel populations to sustain human exploitation.

Acknowledgements. We are very grateful to Jenny Gush, Chris Gray, Carol Simon and Gillian McGregor for their help in the field. We are also indebted to SANCOR, The Foundation for Research Development and the Joint Research Council of Rhodes University for funding.

\section{LITERATURE CITED}

Alvarado JL, Castilla JC (1996) Tridimensional matrices of mussels Perumytilus purpuratus on intertidal platforms with varying wave forces in central Chile. Mar Ecol Prog Ser 133:135-141

Arnold WS, Marelli DC, Bert TM, Jones DS, Quitmyer IR (1991) Habitat-specific growth of hard clams Mercenaria mercenaria (L.) from the Indian River, Florida. J Exp Mar Biol Ecol 147:245-265

Bayne BL (1976) Aspects of reproduction in bivalve molluscs. In: Wiley M (ed) Estuarine processes, Vol 1. Use, stresses and adaptation to the estuary. Academic Press Inc, New York, p 432-448

Bayne BL (1993) Feeding physiology of bivalves: time-dependence and compensation for changes in food availability. NATO ASI Ser G 33:1-24

Berry PF (1978) Reproduction, growth and production in the mussel, Perna perna (Linnaeus), on the east coast of South Africa. Invest Rep Oceanogr Res Inst, Durban 48:1-28

Bertness MD, Grosholz E (1985) Population dynamics of the ribbed mussel, Geukensia demissa: the costs and benefits of an aggregated distribution. Oecologia 67:192-197

Bustamente RH, Branch GM, Eekhout S (1995) Maintenance of an exceptional intertidal grazer biomass in South Africa: subsidy by subtidal kelps. Ecology 76:2314-2329

Cerrato RM, Keith DL (1992) Age structure, growth and morphometric variations in the Atlantic surf clam, Spisula solidissima, from estuarine and inshore waters. Mar Biol 114:581-593

Dare PJ (1976) Settlement, growth and production of the mussel, Mytilus edulis in Morecombe Bay, England. Fishery Invest, Lond (Ser II) 28:1-25

Dayton PK (1971) Competition, disturbance, and community organization: the provision and subsequent utilisation of space in a rocky intertidal community. Ecol Monogr 41: 351-389

Denny MW (1987) Lift as a mechanism of patch initiation in mussel beds. J Exp Mar Biol Ecol 113:231-245

Dey DD, Bolton ET (1978) Tetracycline as a bivalve shell marker. Proc Natl Shellfish Assoc 68:77

Dickie LM, Boudreau PR, Freeman KR (1984) Influences of stock site on growth and mortality in the blue mussel (Mytilus edulis). Can J Fish Aquat Sci 41:134-140

Dye AH (1988) Rocky shore surveillance on the Transkei coast: temporal and spatial variability in the balanoid zone at Dwesa. S Afr J Mar Sci 7:87-99

Dye AH, Schleyer MH, Lambert G, Lasiak TA (1994) Intertidal and subtidal filter-feeders in Southern Africa. In: Siegfried WR (ed) Ecological studies-rocky shores: exploitation in Chile and South Africa. Springer-Verlag, Berlin, p 57-73

Ekaratne SUK, Crisp DJ (1982) Tidal micro-growth bands in intertidal gastropod shells, with an evaluation of banddating techniques. Proc R Soc Lond Ser B 214:305-323

Eyster LS, Pechenik JA (1987) Attachment of Mytilus edulis L. larvae on algal and byssal filaments is enhanced by water agitation. J Exp Mar Biol Ecol 114:99-110

Frechette M, Bourget E (1985) Energy flow between the pelagic and benthic zones: factors controlling particulate organic matter available to an intertidal mussel bed. Can J Fish Aquat Sci 42:1158-1165

Gayanilo FC Jr, Sparre P, Pauly D (1996) The FAO-ICLARM stock assessment tools (FiSAT) user's guide. FAO Comp Info Ser 6:1-186

Grant J, Dowd M, Thompson K, Emerson C, Hatcher A (1993) Perspectives on field studies and related biological models of bivalve growth and carrying capacity. NATO ASI Series G 33:371-420

Griffiths CL, Hockey PAR (1987) A model describing the interactive roles of predation, competition and tidal elevation in structuring mussel populations. S Afr J Mar Sci 5: $547-556$

Griffiths RJ (1980a) Filtration, respiration and assimilation in the black mussel Choromytilus meridionalis. Mar Ecol Prog Ser 3:63-70

Griffiths RJ (1980b) Natural food availability and assimilation in the bivalve Choromytilus meridionalis. Mar Ecol Prog Ser 3:151-156

Griffiths RJ (1981) Population dynamics and growth of the bivalve Choromytilus meridionalis (Kr.) at different tidal levels. Estuar Coast Shelf Sci 12:101-118

Harger JRE, Landenberger DE (1971) The effect of storms as a density dependent mortality factor on populations of sea mussels. Veliger 14:195-201

Jones WE, Demetropoulos A (1968) Exposure to wave action: measurements of an important ecological parameter on rocky shores on Anglesey. J Exp Mar Biol Ecol 2:46-63

Jørgensen CB (1976) Growth efficiencies and factors controlling size in some mytilid bivalves, especially Mytilus edulis L.: review and interpretation. Ophelia 15:175-192

Kaehler S (1999) Incidence and distribution of phototrophic shell-degrading endoliths of the brown mussel Perna perna. Mar Biol 135:505-514

Kaehler S, McQuaid CD (1999a) Use of the fluorochrome calcein as an in-situ growth marker in the brown mussel Perna perna. Mar Biol 133:455-460

Kaehler S, McQuaid CD (1999b) Lethal and sub-lethal effects of phototrophic endoliths attacking the shell of the intertidal mussel Perna perna. Mar Biol 133:497-503

Kautsky N (1982) Growth and size structure in a Baltic Mytilus edulis population. Mar Biol 68:117-133

Kautsky N, Johannesson K, Tedengren M (1990) Genotypic and phenotypic differences between Baltic and North Sea populations of Mytilus edulis evaluated through reciprocal transplantations. I. Growth and morphology. Mar Ecol Prog Ser 59:203-210 
Lasiak T (1986) The reproductive cycles of the intertidal bivalves Crassostrea cucullata (Born, 1778) and Perna perna (Linnaeus, 1758) from the Transkei coast, Southern Africa. Veliger 29:226-230

Lasiak T (1991) The susceptibility and/or resilience of rocky littoral molluscs to stock depletion by the indigenous coastal people of Transkei, Southern Africa. Biol Conserv 56:245-264

Lasiak T, Dye A (1989) The ecology of the brown mussel Perna perna in Transkei, Southern Africa. Implications for the management of a traditional food resource. Biol Conserv 47:245-257

McQuaid CD, Branch GM (1984) Influence of sea temperature, substratum and wave exposure on rocky intertidal communities: an analysis of faunal and floral biomass. Mar Ecol Prog Ser 19:145-151

McQuaid CD, Branch GM (1985) Trophic structure of rocky intertidal communities: response to wave action and implications for energy flow. Mar Ecol Prog Ser 22:153-161

McQuaid CD, Lidsay JR, Lindsay TL (in press) Interactive effects of wave exposure and tidal height on population structure of the mussel Perna perna Linnaeus. Mar Biol

Menge BA (1976) Organization of the New England rocky intertidal community: role of predation, competition, and environmental heterogeneity. Ecol Monogr 46:355-393

Menge BA (1992) Community regulation: under what conditions are bottom-up factors important on rocky shores? Ecology 73:755-765

Newell CR, Shumway SE (1993) Grazing of natural particulates by bivalve molluscs: a spatial and temporal perspective. NATO ASI Series G 33:85-148

Paine RT, Levin SA (1981) Intertidal landscapes: disturbance and the dynamics of pattern. Ecol Monogr 51:145-178

Palumbi SR (1984) Measuring intertidal wave force. J Exp Mar Biol Ecol 81:171-179

Pauly D (1990) Length-converted catch curves and the seasonal growth of fishes. Fishbyte 8:33-38

Pauly D, Munro J (1984) ICLARM's activities in tropical stock assessment: 1979-1984, and beyond. ICLARM Newsl 7: 7-9

Pauly D, Moreau J, Abad N (1995) Comparison of age-structured and length-converted catch curves of brown trout Salmo trutta in two French rivers. Fish Res 22:197-204

Pentilla J, Jearld A, Clark S (1988) Age determination methods for Northwest Atlantic species. NOAA Tech Rep US Dep Commerce 72:3-135

Petraitis PS (1995) The role of growth in maintaining spatial dominance by mussels Mytilus edulis. Ecology 76: 1337-1346

Raubenheimer D, Cook P (1990) Effects of exposure to wave action on allocation of resources to shell and meat growth

Editorial responsibility: Roger Hughes (Contributing Editor), Bangor, Wales, UK by the subtidal mussel, Mytilus galloprovincialis. J Shellfish Res 9:87-93

Richardson CA (1989) An analysis of the microgrowth bands in the shell of the common mussel Mytilus edulis. J Mar Biol Assoc UK 69:477-491

Richardson CA, Seed R, Naylor E (1990) Use of internal growth bands for measuring individual and population growth rates in Mytilus edulis from offshore production platforms. Mar Ecol Prog Ser 66:259-265

Seed R (1968) Factors influencing shell shape in the mussel Mytilus edulis. J Mar Biol Assoc UK 48:561-584

Seed R (1969) The ecology of Mytilus edulis L. (Lamellibranchiata) on exposed rocky shores. II. Growth and mortality. Oecologia 3:317-350

Seed R (1976) Ecology. In: Bayne BL (ed) Marine mussels: their ecology and physiology. Cambridge University Press, Cambridge, p 13-65

Shafee MS (1992) Production estimate of a mussel population Perna picta (Born) on the Atlantic coast of Morocco. J Exp Mar Biol Ecol 163:183-197

Shepherd JG (1987) A weakly parametric method for estimating growth parameters from length composition data. In: Pauly D, Morgan GR (eds) Length-based methods in fisheries research. International Center for Living Aquatic Resources Management, Manila, Philippines, Kuwait, p 113-119 (Proc 13th Int Center Living Aquat Resourc Mgmt [ICLARM])

Sparre P, Venema SC (1993) Introduction to tropical fish stock assessment. Part I manual. FAO Fish Tech Pap 306/1 (Rev 1):1-376

Stirling HP, Okumus I (1994) Growth, mortality and shell morphology of cultivated mussel (Mytilus edulis) stocks cross-planted between two Scottish sea lochs. Mar Biol 119:115-123

Suchanek TH (1985) Mussels and their role in structuring rocky shore communities. In: Moore PG, Seed R (eds) The ecology of rocky coasts. Columbia University Press, New York, p 70-96

Tomalin BJ (1995) Growth and mortality rates of brown mussels Perna perna (Linnaeus) in Kwazulu-Natal: a comparison between sites and methods using non-parametric length-based analysis. S Afr J Mar Sci 16:241-254

Tsuchiya M (1980) Biodeposit production by the mussel Mytilus edulis L. on rocky shores. J Exp Mar Biol Ecol 47: 203-222

van Erkom Schurink C, Griffiths CL (1993) Factors affecting relative rates of growth in four South African mussel species. Aquaculture 109:257-273

Wetherall JA (1986) A new method for estimating growth and mortality parameters from length-frequency data. Fishbyte $4: 12-14$

Submitted: September 22, 1999; Accepted: May 30, 2000 Proofs received from author(s): October 16, 2000 